\title{
Impact of Green Initiatives on the Financial Performance of Small and Medium Enterprises: The Case of Manufacturing Firm in Central Luzon
}

\author{
Ma. Teresa B. Alfaro a (D), Rowell Agliones Diaz b ${ }^{\text {b }}$ \\ ${ }^{a}$ Graduate School Professor, Nueva Ecija University of Science and Technology, Gen. Tinio Campus, \\ Cabanatuan City, 3100, Nueva Ecija, Philippines, mbalfaro0109@gmail.com \\ ${ }^{\mathrm{b}}$ Business and Management Faculty, Nueva Ecija University of Science and Technology, San Isidro Campus, \\ (Tabon), San Isidro, 3110, Nueva Ecija, Philippines, rowell.diaz@neust.edu.ph
}

Recibido: 2020-10-25 Aceptado: 2021-04-12

To cite this article: Alfaro, $\mathrm{M}^{\mathrm{a}}$ Teresa B.; Diaz, Rowell Agliones, (2021). Impact of Green Initiatives on the Financial Performance of Small and Medium Enterprises: The Case of Manufacturing Firm in Central Luzon. WPOM-Working Papers on Operations Management, 12 (1), 28-41.

doi: https://doi.org/10.4995/wpom.v12i1.14517

\begin{abstract}
This study was conducted to propose the Green Economic Development Plan or G.E.D. plan which may be used as guide by Small and Medium Manufacturing Enterprises or S.M.M.E.s to achieve a more competitive advantage. The researcher was inspired by the theory of sustainable development where green practitioners ensure that business processes are geared towards the preservation of the natural environment. Green practices ensure that natural environment is protected, sources of local supplies and raw materials are sustained, total costs and expenses are reduced and net income are increased, hence, businesses become more resilient and competitive. More resilient and competitive businesses contribute to economic development which will benefit the whole community. The descriptive survey method was used to gather data to determine the green initiatives that were implemented by S.M.M.E.s and were used as bases for crafting a green economic development plan or G.E.D. plan. Document analysis was also employed to obtain data from any available printed materials and records provided by the respondents. Observation was also employed to survey the assets owned and validate any green initiatives that were implemented by the S.M.M.E.s. Such methods of gathering information were used to validate data gathered from local and foreign-related literature. The findings showed that among the green initiatives implemented by S.M.M.E.s, which resulted in the reduction of total costs and expenses, were the proper disposal and segregation of waste materials, water management by recycling wastewater and using water-efficient equipment, installing energyefficient equipment, using eco-friendly packaging materials and local supplies,
\end{abstract}


Impact of Green Initiatives on the Financial Performance of Small and Medium Enterprises Ma. T. B. Alfaro, R. A. Diaz

managing efficiently natural resources and raw materials.

Having analyzed the findings it was recommended that the S.M.M.E.s should encourage active participation and support of suppliers and customers in achieving the G.E.D.'s objectives by developing incentive schemes. Furthermore, S.M.M.E.s should continue to benchmark with Green Practitioners that are operating locally and abroad to adopt best greening strategies and regularly network with concerned government agencies for continuous updating on Green Economic Development initiatives that may benefit the firm. Further research may be conducted on green initiatives implemented by small and medium enterprises in other industry sectors.

Keywords: Green Initiatives, Economic Growth, Social Development, Green Economic Development Plan, Financial Performance.

\section{Introduction}

The Green Economy is the term used to refer to an economy that aims to promote economic development while preserving the environment. The business term for "green" is now widely used, although its origins lie more in the popular press than the scientific community (Baines, et al., 2012). It aims to strengthen sustainable development without compromising the environment. In this context, the workers or personnel play a vital role in the sustainability of the business through the green initiatives that were implemented in business operations. For example, in the 2017 Sustainability Report of SM Investments included raising awareness and financing for renewable energy and energy-efficiency projects. Clients and stakeholders were mostly micro, small and medium enterprises and SM Investments demanded the same green initiative commitment from them. As to infrastructure and roadworks, SM Prime ensured that disaster-resilient features were incorporated in the design of housing development to reduce the impact of climate change on the building and road networks. Waste water in offices and stalls was recycled and used for non-potable purposes.

The physical environment may be affected by the business activities, and changes in the environment could also dictate changes in the latter's activities. Every business, directly and indirectly, impacts the environment. (Nassani, et. al, 2019; Ogega, 2017).

The challenge now for business enterprises is to balance the desire to create wealth and maintain a clean and sustainable environment. This can be achieved by applying the theory of environmental economics. In their study, Waheed, et. al. (2020) emphasized that to pursue sustainability in all business operations is a notable challenge for firms to survive in today's competitive environment. It was emphasized by Field and Field (2009) that economics focuses on how an economy and its institutions are set up and how transforming and managing scarce resources increase human wealth. There was a significant relationship between environmental costs and a firm's earning capacity. (Beredugo, 2014). Furthermore, the environment-related costs considered in his study were "costs incurred in preventing, reducing and repairing damages to the environment and social cost incurred to recognize the organization's responsiveness to the society at large. Other business enterprises operated so that as business activities increased, wastes from packaging materials also increased. (Skrabania, 2018). Online shopping is a lucrative business and is now the current trend. On the one hand, an increasing number of entrepreneurs engaging in this type of business is good for the 
economy. On the other hand, as the business entity grows, wastes from packaging materials also increase. As more packaging materials are used, more trash could destroy the environment and be thrown into the landfill.

Other researchers also emphasized the importance of accounting for all costs, including Deegan (2013), who emphasized the importance of identifying resources used and measuring and communicating its costs. Product design and processes also entail costs as Tu and Huang (2015) enthused. They cited Tu (2005), who stated that the green concept is environment-oriented, which meant that environmental concerns carried the same weight as profitability product design and development process. In other words, the green concept is concerned with the environment and its impact on business activities, especially the business' earning capacity. The findings would be the basis for developing the Green Economic Development Plan to help organize programs, projects, or activities geared towards preserving the environment and reducing total costs and expenses. By implementing environmentally friendly initiatives, business enterprises would adapt to extreme weather conditions and stay competitive. A small number of firms have already made significant progress in responding to the environmental challenge. (Marcus and Willig, 1997).

T hrough the Green Economic Development Program, an increased number of Small and Medium Manufacturing Enterprises (S.M.M.E.s) become more aware of the importance of green initiatives to their businesses' financial well-being, by increasing their capacity to bounce back in case of calamities brought about by climate change and global warming. Globally there is mounting pressure for firms to assess their impact on the environment and modify their behavior accordingly. (Cassells \& Lewis, 2011). When more business enterprises become more resilient economically, this would mean more secured employment for people at the regional and provincial levels, making a positive impact on the economy at the national level.

This research study investigated the influence of green initiatives implemented by small and medium manufacturing enterprises. Careful analysis of the green initiatives and barriers were done to understand any significant impacts of such business practices on the green practitioners' financial performance. The information obtained would be the basis for the crafting of the Green Economic Development Plan.

\section{Methods}

Purposive sampling is a technique used to select categories from the target population. There was no complete list of green practitioners in the manufacturing industry categorized as small and medium enterprises that used local supplies as raw materials. Questionnaires were administered to 100 small and medium manufacturing enterprises to learn about the green processes that were being implemented. This number was narrowed down to the number shown here. The remaining number of Small and Medium Manufacturing Enterprises were those who had commonalities in the location of the business, business structures, production processes and other significant environment-friendly activities included in the study. The commonalities that were stated were essential for careful analysis of the data that were gathered, to arrive at the conclusion. The requirements for small and medium manufacturing enterprises in selecting samples using purposive sampling included:1. being registered in Central Luzon particularly in Nueva Ecija, Tarlac, Pampanga, and Bulacan; 2. had been operating for three (3) years or more; and 3. the firm's ownermanager or manager should have managed the business for at least two years.

The researcher chose respondents from the manufacturing industry involved in food processing because of the big number of establishments of this type that are operating and providing work for a greater number of employees compared to other industries as discussed in the 2016 Annual Survey of Philippine Business 
and Industry by the Philippine Statistics Authority. This type of business' economic situation and sustainability are crucial to maintaining a high rate of employment. The respondents in this study identified only as S.M.E. A, S.M.E. B, and so on until S.M.E. I, to keep the identity of the respondents as promised by the researcher when the interview was done because details of their financial information were gathered, including information on business practices and operations that were useful for analyzing and interpreting the data gathered. For purposes of clarity of discussion, the following information regarding the respondents are shown:

S.M.E. A manufactures bread, pastries, and cakes

S.M.E. B manufactures dairy products

S.M.E. C manufactures meat and meat products

S.M.E. D manufactures meat and meat products

S.M.E. E manufactures food supplements

S.M.E. F manufactures dairy products

S.M.E. G manufactures fruit juice, preserved fruits, and pastries

S.M.E. H manufactures fruit juice, preserved fruits, and other fruit products S.M.E. I manufactures bread, pastries, cakes

The unstructured, informal interview included open-ended questions with no prepared response choices. This part allowed the interviewee to shift the direction of the interview. In this way, the researcher could gather unanticipated information to supplement any data gathered through the questionnaire.

Issues and problems that challenged small and medium manufacturing enterprises or S.M.M.E.s were gathered from case studies and other research works, newspapers and magazines, books, and other reading materials, including sustainability reports, articles, and other written documents that were accessed on various websites. The information gathered was then examined. Past and present data were compared to understand better the economic conditions of S.M.M.E.s before and after implementation of green initiatives and to investigate how green initiatives were useful in improving the capacity of the S.M.M.E.s to adapt to extreme weather conditions.

Survey questionnaires were researcher-developed and these were validated for correctness and reliability. Pre survey was done to test whether or not respondents could understand questions in the survey questionnaires and that the questions would be interpreted correctly, or questions would not influence respondents in the way they responded.

In analyzing the impact of green initiatives on the respondents' financial performance, respondents were asked to show which of the various green initiatives reduced total expenses. As discussed previously, a reduction in total costs and expenses would result in higher net income, and an increase in net income also increase Owner's Equity. The frequency was used to assess how many of the respondents experienced a reduction in total expenses because of the green initiatives that they have implemented. The decrease in total expenses was analyzed based on the estimated amount of reduction, and the respondents were requested to rate their choices from ' 1 to 4 '. For example, a green initiative which was implemented and had a very significant impact on the financial performance of the business was rated at ' 4 ', which meant that there was more than $50 \%$ decrease in total expenses, Significant impact or rated ' 3 ' meant that there was $50 \%$ decrease in total expenses, those green initiatives that resulted in less than $50 \%$ decrease in total expenses were rated at ' 2 ' and the green initiative with no recorded impact on financial performance was rated at' 1 '. No impact when green initiatives did not result in a decrease in the total expenses of the enterprise. 
Impact of Green Initiatives on the Financial Performance of Small and Medium Enterprises Ma. T. B. Alfaro, R. A. Diaz

\section{Results \& Discussion}

\section{Impact of Green Initiatives on the Financial Performance of the Small and Medium Manufacturing Enterprises}

All of the respondents used machines in their production activities. That is, the production process was either fully automated or partially automated. Only one of the respondents depended on machines for all manufacturing processes, and $88.87 \%$ were on partial automation. The manufacturing enterprises with partial automation had total expenses falling at different ranges because they used different machines. In the manufacturing process, the types of expenses incurred in creating finished goods from raw materials were categorized into the cost of raw materials, direct labor, and manufacturing overhead. (Ballada and Ballada, 2018). Manufacturing overhead consisted of the cost of electricity and water consumed and workers' wages in the production area but not directly involved in creating products. Table 1 shows the respondents' total expenses as part of their operating costs, including electricity, water, and raw materials.

Table 1. Estimated Average Total Expenses of the Respondents in Terms of Electricity, Water and Supplies and Materials

\begin{tabular}{|c|c|c|c|}
\hline Small and Medium Enterprises & Electricity & Water & $\begin{array}{c}\text { Supplies and } \\
\text { Materials }\end{array}$ \\
\hline SME A & P1,200,000 & $\mathrm{P} 36,000$ & $\mathrm{P} 500,000$ \\
\hline SME B & $\mathrm{P} 288,000$ & $\mathrm{P} 50,000$ & $\mathrm{P} 450,000$ \\
\hline SME C & $\mathrm{P} 400,000$ & $\mathrm{P} 40,000$ & $\mathrm{P} 100,000$ \\
\hline SME D & $\mathrm{P} 500,000$ & $\mathrm{P} 80,000$ & $\mathrm{P} 180,000$ \\
\hline SME E & $\mathrm{P} 500,000$ & $\mathrm{P} 50,000$ & $\mathrm{P} 100,000$ \\
\hline SME F & $\mathrm{P} 215,000$ & $\mathrm{P} 36,000$ & $\mathrm{P} 325,000$ \\
\hline SME G & $\mathrm{P} 150,000$ & $\mathrm{P} 26,000$ & $\mathrm{P} 420,000$ \\
\hline SME H & $\mathrm{P} 144,000$ & $\mathrm{P} 21,000$ & $\mathrm{P} 75,000$ \\
\hline SME I & $\mathrm{P} 125,000$ & $\mathrm{P} 60,000$ & $\mathrm{P} 250,000$ \\
\hline
\end{tabular}

Only $22.22 \%$ of the respondents declared an increase in investment due to the expansion made in their firm during the period from 2017 to 2019 . However, they also said that there had been a decrease in total expenses due to the implementation of green initiatives. Among the respondents, $66.67 \%$ declared a decrease in total expenses, which increased net revenue resulting in increased capital.

The discussion that follows is about the impact of green initiatives on the financial performance of enterprises. As previously discussed, green initiatives are of different types; some involve savings on materials, water and electricity conservation, prevention of pollution, etc. Various researchers had studied the impact of green initiatives on the financial performance of business enterprises. Rowlands (2019) stated that there was increasing demand worldwide for eco-friendly products sold in eco-friendly packaging. According to Rowlands (2019), eco-friendly packaging was sustainable, recyclable, reduces carbon footprint, and would entail lower shipping costs; hence, the business enterprise would earn more from the sale of eco-friendly products. Vachon and Klassen (2008) emphasized the benefits of collaborative green practices with suppliers and consumers. Accordingly, suppliers are expecting to supply raw materials produced by green manufacturing processes. Many consumers preferred to buy goods produced using eco-friendly processes and distributed packaging that did not harm the environment.

Based on data gathered and analyzed by the researcher, green practices implemented by the selected small and medium manufacturing enterprises affected their financial performance. Jabbour de Sousa et al. (2019) 
emphasized that while the manufacturing sector is the largest creator of employment they also consume a large part of the world's natural resources. Green initiatives such as those implemented in terms of 1 . electricity conservation; 2 . water conservation; 3 . proper materials management; 4 . proper waste management which included pollution prevention and recycling and upcycling of scrap materials; and 5. reduction of packaging materials; impact the financial performance of a business enterprise more than any other type of green initiative does, hence, for discussion purposes, green initiatives are group as such.

Some of the S.M.E.s' green initiatives to conserve electricity and reduce total expenses can be seen in the following table. Also shown are the computations of the impact of the green initiatives on S.M.E.s' financial performance using the tool for quick potential savings estimation provided by ProGED (Promotion for Green Economic Development). The tool based on an electricity rate of P10.50 per kilowatt-hour and for a period of the basic daily 8 -hour work.

In conserving electricity, some of the strategies used were scheduling the time of switching on and switching off air conditioning units. The temperature was to be fixed at $25^{\circ} \mathrm{C}$, changing fluorescent bulbs to L.E.D. bulbs, and so on. The data on the number of air conditioning units used, air conditioning unit temperatures maintained, and the number of L.E.D. Bulbs used were gathered through the interview and ocular inspection of the building to validate the respondent's information.

The electricity-saving scheme of scheduling the switching-on and switching-off of the air conditioning units used in rooms were based only on 8 hours. Air conditioning units were switched on only at 9:00 a.m. and switched off at 4:00 p.m. Air conditioning before 9:00 a.m. and after 4:00 p.m. may not be necessary because rooms would be cooler by then.

The scheme did not include areas where a particularly lower temperature must be maintained to keep devices and machines in optimum operating capacity. Table 2 shows the computation of savings on electricity consumption obtained from scheduling the switching-on and switching-off air conditioning units.

Table 2. Savings on Electricity Consumption Based on Scheduling of Switching on and Switching Off of Air conditioning units.

\begin{tabular}{|c|c|c|c|c|c|}
\hline $\begin{array}{c}\text { Small and Me- } \\
\text { dium Enter- } \\
\text { prises }\end{array}$ & $\begin{array}{c}\text { Number of } \\
\text { Aircon } \\
\text { Units Used }\end{array}$ & $\begin{array}{c}\text { Savings in kw used } \\
\text { after Implementa- } \\
\text { tion of Green } \\
\text { Initiative per } \\
\text { month }\end{array}$ & $\begin{array}{c}\text { Total Savings } \\
\text { in } \\
\text { kw used } \\
\mathbf{( 2 )} \mathbf{X}(\mathbf{1})\end{array}$ & $\begin{array}{c}\text { Rate per kw } \\
\text { used } \\
\mathbf{P 1 0 . 5 0}\end{array}$ & $\begin{array}{c}\text { Estimated Savings } \\
\text { on Electricity } \\
\text { Consumption per } \\
\text { month } \\
\mathbf{( 3 ) ~ X ~ ( 4 ) ~}\end{array}$ \\
\hline SME A & $\mathbf{( 1 )}$ & $\mathbf{( 2 )}$ & $\mathbf{( 3 )}$ & $\mathbf{( 4 )}$ & $\mathbf{( 5 )}$ \\
\hline SME B & 6 & 500 & 3,000 & $\mathrm{P} 10.50$ & $\mathrm{P} 31,500$ \\
\hline SME C & 6 & 500 & 1,500 & $\mathrm{P} 10.50$ & $\mathrm{P} 15,750$ \\
\hline SME D & 3 & 500 & 3,000 & $\mathrm{P} 10.50$ & $\mathrm{P} 31,500$ \\
\hline SME E & 5 & 500 & 1,500 & $\mathrm{P} 10.50$ & $\mathrm{P} 15,750$ \\
\hline SME F & 6 & 500 & 2,500 & $\mathrm{P} 10.50$ & $\mathrm{P} 26,250$ \\
\hline SME G & 3 & 500 & 3,000 & $\mathrm{P} 10.50$ & $\mathrm{P} 31,500$ \\
\hline SME H & 3 & 500 & 1,500 & $\mathrm{P} 10.50$ & $\mathrm{P} 15,750$ \\
\hline SME I & 5 & 500 & 1,500 & $\mathrm{P} 10.50$ & $\mathrm{P} 15,750$ \\
\hline & & 500 & 2,500 & $\mathrm{P} 10.50$ & $\mathrm{P} 26,250$ \\
\hline
\end{tabular}

Another green initiative implemented to reduce electricity consumption was setting the temperature at $25^{\circ} \mathrm{C}$ instead of the usual $18^{\circ} \mathrm{C}$. The actual kilowatt used per unit was $25 \mathrm{kw}$ at an estimated number of hours used 
of 300 hours per month. The estimated monthly savings on electricity under this scheme was P2,100. Table 3 shows savings on electricity by controlling the temperature of air conditioning units used.

Table 3. Savings on Electricity Consumption Based on Setting of the temperature at $25^{\circ} \mathrm{C}$ of Air conditioning units.

\begin{tabular}{|c|c|c|c|c|c|}
\hline S.M.E. & $\begin{array}{c}\text { Number } \\
\text { of Air } \\
\text { con Units } \\
\text { Used }\end{array}$ & $\begin{array}{c}\text { Estimated } \\
\text { number of } \\
\text { hours used } \\
\text { per month }\end{array}$ & $\begin{array}{c}\text { Estimated kw } \\
\text { savings per air } \\
\text { con unit used } \\
\text { per month }\end{array}$ & $\begin{array}{c}\text { Rate per kw } \\
\text { used } \\
\mathbf{P 1 0 . 5 0}\end{array}$ & $\begin{array}{c}\text { Estimated Savings on } \\
\text { Electricity } \\
\text { Consumption per } \\
\text { month } \\
\text { (1)x(3)x(4) }\end{array}$ \\
\hline SME A & $\mathbf{( 1 )}$ & $\mathbf{( 2 )}$ & $\mathbf{( 3 )}$ & $\mathbf{( 4 )}$ & $\mathbf{( 5 )}$ \\
\hline SME B & 6 & 300 & 2,100 & $\mathrm{P} 10.50$ & $\mathrm{P} 132,300$ \\
\hline SME C & 6 & 300 & 2,100 & $\mathrm{P} 10.50$ & $\mathrm{P} 66,150$ \\
\hline SME D & 3 & 300 & 2,100 & $\mathrm{P} 10.50$ & $\mathrm{P} 132,300$ \\
\hline SME E & 5 & 300 & 2,100 & $\mathrm{P} 10.50$ & $\mathrm{P} 66,150$ \\
\hline SME F & 6 & 300 & 2,100 & $\mathrm{P} 10.50$ & $\mathrm{P} 110,250$ \\
\hline SME G & 3 & 300 & 2,100 & $\mathrm{P} 10.50$ & $\mathrm{P} 132,300$ \\
\hline SME H & 3 & 300 & 2,100 & $\mathrm{P} 10.50$ & $\mathrm{P} 66,150$ \\
\hline SME I & 5 & 300 & 2,100 & $\mathrm{P} 10.50$ & $\mathrm{P} 66,150$ \\
\hline & & & 2,100 & $\mathrm{P} 10.50$ & $\mathrm{P} 110,250$ \\
\hline
\end{tabular}

The table shows the total savings from electricity, assuming all air conditioning units were used all at the same time for 300 hours a month. The estimated total savings on electricity consumption by setting the temperature at $25^{\circ} \mathrm{C}$ was 2,100 kilowatts per month per unit. The total estimated savings on electricity per month computed by multiplying the number of units used by the kilowatt savings of 2,100 and the rate per kilowatt-hour of P10.50. The greater number of air conditioning units used, the more the savings would be when temperatures fix at $25^{\circ} \mathrm{C}$.

Another green initiative implemented by the small and medium enterprise respondents impacted their financial performance was changing the lighting systems from standard bulbs to L.E.D. Bulbs. Nguyen et al., (2020) on their study shows that customer green innovation taxonomies influence differently on environmental measures, costs, and financial performance. Table 4 shows the computation of savings on the electricity consumption of small and medium enterprises.

Table 4. Savings on Electricity Consumption from Change of Lighting to L.E.D. Bulbs.

\begin{tabular}{|c|c|c|c|c|c|}
\hline $\begin{array}{c}\text { Small and Medium En- } \\
\text { terprises }\end{array}$ & $\begin{array}{c}\text { Estimated } \\
\text { Number of } \\
\text { L.E.D. } \\
\text { bulbs Used }\end{array}$ & $\begin{array}{c}\text { Estimated } \\
\text { number of } \\
\text { hours used } \\
\text { per month }\end{array}$ & $\begin{array}{c}\text { Estimated kw } \\
\text { savings } \\
\text { Per month } \\
{[\mathbf{6 6 0} \div \mathbf{1 1 0}] \mathbf{x} \text { (1) }}\end{array}$ & $\begin{array}{c}\text { Rate per } \\
\mathbf{k w} \\
\text { used } \\
\mathbf{P 1 0 . 5 0}\end{array}$ & $\begin{array}{c}\text { Estimated Sav- } \\
\text { ings on Electric- } \\
\text { ity } \\
\text { Consumption per } \\
\text { month } \\
\mathbf{( 3 ) x ( 4 )}\end{array}$ \\
\hline & $\mathbf{( 1 )}$ & $\mathbf{( 2 )}$ & $\mathbf{( 3 )}$ & $\mathbf{( 4 )}$ & $\mathbf{( 5 )}$ \\
\hline SME A & 110 & 300 & 660 & $\mathrm{P} 10.50$ & $\mathrm{P} 6,930$ \\
\hline SME B & 20 & 300 & 120 & $\mathrm{P} 10.50$ & $\mathrm{P} 1,260$ \\
\hline SME C & 80 & 300 & 480 & $\mathrm{P} 10.50$ & $\mathrm{P} 5,040$ \\
\hline SME D & 40 & 300 & 240 & $\mathrm{P} 10.50$ & $\mathrm{P} 2,520$ \\
\hline SME E & 110 & 300 & 660 & $\mathrm{P} 10.50$ & $\mathrm{P} 6,930$ \\
\hline SME F & 80 & 300 & 480 & $\mathrm{P} 10.50$ & $\mathrm{P} 5,040$ \\
\hline SME G & 30 & 300 & 180 & $\mathrm{P} 10.50$ & $\mathrm{P} 1,890$ \\
\hline SME H & 20 & 300 & 120 & $\mathrm{P} 10.50$ & $\mathrm{P} 1,260$ \\
\hline SME I & 50 & 300 & 300 & $\mathrm{P} 10.50$ & $\mathrm{P} 3,150$ \\
\hline
\end{tabular}

The estimated number of kilowatt savings for 110 units is 660 or 6-kilowatt savings per one L.E.D. Bulb. The total estimated kilowatt savings per month is multiplied by the kilowatt rate of P10.50 to compute the estimated savings in electricity consumption per month due to the green initiative of changing ordinary 
bulbs with more electricity-efficient L.E.D. Bulbs. This is based on the tool for quick potential savings estimation as provided by ProGED (Promotion for Green Economic Development).

Most respondents' total water bill did not involve large amounts. Any effect of the reduction in water expenses was not that significant, except for $22.22 \%$ of respondents whose manufacturing processes involved lots of water usage for cleaning up the work area. Hence, they said that any reduction in the total water expenses resulting from using wastewater for non-potable purposes had a significant effect on the firms' financial performance. About $44.44 \%$ said that the green initiatives resulted in at least a $50 \%$ decrease in total expenses. Regarding using dual-flush converters, $33.33 \%$ of the respondents' total expenses were reduced only significantly, which is at least a $50 \%$ decrease in total expenses. To install an automatic shut-off or low-flow nozzle, $66.67 \%$ reported a very insignificant effect on total expenses. Table 5 shows the savings on water conservation that impacted the financial performance of the manufacturing enterprises.

Table 5. Savings on Water Conservation

\begin{tabular}{|c|c|c|c|}
\hline $\begin{array}{c}\text { Small and Medium } \\
\text { Enterprises }\end{array}$ & $\begin{array}{c}\text { Estimated water con- } \\
\text { sumption per month be- } \\
\text { fore green initiatives }\end{array}$ & $\begin{array}{c}\text { Estimated water con- } \\
\text { sumption per month after } \\
\text { green initiatives }\end{array}$ & $\begin{array}{c}\text { Estimated Savings on } \\
\text { Water Consumption } \\
\text { per month }\end{array}$ \\
\hline & $\mathbf{( 1 )}$ & $\mathbf{( 2 )}$ & $\mathbf{( 4 )}$ \\
\hline SME A & $\mathrm{P} 3,000$ & $\mathrm{P} 2,250$ & $\mathrm{P} 750$ \\
\hline SME B & 3,000 & 2,000 & $\mathrm{P} 1,000$ \\
\hline SME C & 10,000 & 4,000 & $\mathrm{P} 6,000$ \\
\hline SME D & 10,000 & 8,000 & $\mathrm{P} 2,000$ \\
\hline SME E & 20,000 & 18,000 & $\mathrm{P} 2,000$ \\
\hline SME F & 3,000 & 2,400 & $\mathrm{P} 600$ \\
\hline SME G & 3,000 & 2,400 & $\mathrm{P} 1,300$ \\
\hline SME H & 1,800 & 500 & $\mathrm{P} 4,000$ \\
\hline SME I & 6,000 & 2,000 & \\
\hline
\end{tabular}

As previously discussed, proper waste disposal was considered by a majority of the respondents as important. Those who considered that proper disposal of waste materials did not impact their financial performance had a large amount of bulky trash every day of their operations. Most industrial assets use a significant amount of energy and create waste (Dal Pont et al., 2014.

Regular maintenance of machinery and equipment was observed by $55.55 \%$ of the respondents because they knew that a large amount of the operating costs could be used for the repairs and maintenance of machinery and equipment. They also added that the operations would be significantly affected when machinery shut down. Hence, the green initiative was reported by $55.55 \%$ of the respondents as resulting in a $50 \%$ decrease in the total expenses. The same green initiative was reported by $22.22 \%$ of the respondents as an item that resulted in less than $50 \%$ decrease in total expenses. The remaining $22.22 \%$ did not report any reduction in financial performance.

Putting up posters as a reminder to employees to help prevent pollution resulted in a more than $50 \%$ decrease in total expenses, reported by $33.33 \%$ of the respondents. However, the same percentage said that the green initiative did not affect their firms' financial performance, and the same number of respondents reported less than $50 \%$ decrease in total expenses.

Upcycling of scrap raw materials could reduce the trash in the buildings and surroundings of the business enterprises; however, only $33.33 \%$ of the respondents reported that upcycling and converting scrap materials into valuable goods significantly reduced the total expenses of the firm. About $44.44 \%$ reported that 
upcycling raw materials did not affect financial performance, and 55.55\% reported that converting scrap materials into usable items did not affect their firm's financial performance. Upcycling old magazines and newspapers were reported by $11.11 \%$ of the respondents as not affecting the financial performance, $22.22 \%$ reported that this green initiative resulted in less than a $50 \%$ decrease in the total expenses.

According to the respondents, recycling paper was beneficial to business enterprises, and it was a green initiative that was easy to implement. However, some respondents did not want to implement this because they did not want confidential information to be accidentally exposed.

Recycling containers as rubbish bins and recycling paper were green initiatives reported by $55.55 \%$ of respondents, resulting in more than $50 \%$ decrease in total expenses. Instead of buying new bins to be used to keep trash, they used recycled containers. Much was saved by recycling papers for printing documents; however, $11.11 \%$ of the respondents said that this green initiative is not to implement in his firm; hence, there was no effect of such an item on his financial performance. About $22.22 \%$ of the respondents reported that green initiatives resulted in less than a $50 \%$ decrease in total expenses. Only $33.33 \%$ of the respondents who used recycled materials as decorations reported a $50 \%$ decrease in total expenses, the same percentage reported less than $50 \%$ decrease in total expenses, $22.22 \%$ of the respondents reported a $50 \%$ decrease in total expenses, and only one respondent reported that the green initiative did not affect the financial performance.

Membership in organizations and clubs and participating in social activities were reported by $22.22 \%$ of the respondents as a green initiative that significantly affects their financial performance. Of the enterprises that organized pro-environment activities, $44.44 \%$ reported more than a $50 \%$ decrease in total expenses because some said they could share in the costs and expenses with other organization members or get funding from clubs and organizations had a membership. To participate in social activities and promote environmental protection, $55.55 \%$ reported that the green initiative did not affect. These were the same people who did not have membership in any organization or club that advocate environmental protection.

At the time of interview, some respondents were still thinking of various ways of redesigning their packaging. The packaging materials they were using were still sufficient and ensured of products' safety ducts while in transit.

Some respondents spent much on packaging materials to ensure that their products reached the customers in good condition. However, with packaging that required a lot of paper and plastic, more trash would be left around, which could be detrimental to the environment. That is why recycling is important in green manufacturing. The importance of industrial recycling and remanufacturing is growing due to increas- ing environmental and economic pressures (Eguia, et al., 2011)

Only $22.22 \%$ of the respondents reported a very significant decrease in the total expenses due to reducing packaging materials used; $33.33 \%$ of the respondents reported a significant decrease in total expenses, and the same percentage of respondents reported that the green initiative did not affect the financial performance of the firm. The respondents who reported that there was only a significant decrease in total expenses was only $11.11 \%$. As to redesigning packaging, $33.33 \%$ of respondents reported a significant impact on financial performance because they did not have to spend too much on packaging materials. The same percentage reported that the green initiative did not affect their financial performance. Respondents who reported that the green initiative resulted only in less than $50 \%$ decrease in total expenses was $11.11 \%$, and $33.33 \%$ of the respondents reported a $50 \%$ decrease in total expenses.

Vachon and Klassen (2008) concluded that when business enterprises would like to achieve envi- ronmental sustainability by reducing pollution and other environmental impacts, they can work together with their 
suppliers for eco-friendly manufacturing processes and customers for eco-friendly product pack- aging. As discussed previously, purchasing recycled materials and purchasing from suppliers who sup- ported environmental protection advocacy were among the green initiatives that were considered those that could impact the financial performance. This is where cooperation and coordination with the suppliers of raw materials and the small and medium enterprises are needed most.

Only $33.33 \%$ of the respondents reported that purchasing from suppliers that advocate a green economy resulted in more than $50 \%$ decrease in total expenses, but $44.44 \%$ of the respondents reported the same significant effect on financial performance due to purchasing recycled materials. According to these respondents, recycled materials were cheaper than those who were not recycled. Still, they were quick to emphasize that the recycled materials did not reduce their products' quality. About $55.55 \%$ of the respondents experienced that recycled materials' purchase did not affect their financial performance. Only $44.44 \%$ of the respondents said the same about the effect of purchasing from and supporting suppliers that advocate a green economy. Only $11.11 \%$ of the respondents reported that the green initiatives resulted in a $50 \%$ decrease in total expenses; the same percentage reported the same effect of purchasing from and supporting suppliers who advocate a green economy.

\section{Proposed Green Economic Development Plan}

Through the Department of Trade and Industry or D.T.I. that spearheaded the green economic development project that aims to enhance the competitiveness of Micro, Small and Medium Enterprises (MSMEs). This is done by helping them adopt climate-smart, environmentally friendly, and inclusive strategies and measures by placing with the Green Value Chain (G.V.C) approach to identify hotspots for greening" ( ProGED 2019).

Based on the study results, the following Proposed Green Economic Development (G.E.D.) Plan wasprepared and recommended for small and medium enterprises to use. With the support of the government through the D.T.I., the Small and Medium. Manufacturing Enterprises or S.M.M.E.s will become more resilient and competitive. As the corporate business world is going global, the business is experiencing a shift from a traditional financial structure to a modern capacity-based economy ready to explore the business' green economic facets (Shoeb Ahmad, 2015). 
Impact of Green Initiatives on the Financial Performance of Small and Medium Enterprises Ma. T. B. Alfaro, R. A. Diaz

Table 6. Green Economic Development Three-Year Plan (2020-2023)

\begin{tabular}{|c|c|c|c|c|c|}
\hline AREA & STRATEGY & $\begin{array}{c}\text { PROGRAM/ } \\
\text { ACTIVITY/PROJECT }\end{array}$ & $\begin{array}{l}\text { RESPONSIBLE } \\
\text { UNIT }\end{array}$ & $\begin{array}{c}\text { TIME } \\
\text { FRAME }\end{array}$ & $\begin{array}{l}\text { BUDGET OR } \\
\text { RESOURCES }\end{array}$ \\
\hline \multirow[t]{8}{*}{1} & $\begin{array}{l}\text { Efficient utilization of } \\
\text { energy }\end{array}$ & $\begin{array}{l}\text { Replacement of Non- LED bulbs with L.E.D. } \\
\text { Bulbs. }\end{array}$ & \begin{tabular}{|l} 
Repairs and \\
Maintenance Unit
\end{tabular} & $2020-2022$ & $\mathrm{P} 100,000$ \\
\hline & & $\begin{array}{l}\text { Schedule of switching on at } 9 \text { a.m. and shutting } \\
\text { off of A.C. at } 4 \text { p.m. or before end of office hours. }\end{array}$ & Department or Unit Heads & $2020-2023$ & None \\
\hline & & Setting A.C. temperature at $25^{\circ} \mathrm{C}$ & Department or Unit Heads & $2020-2023$ & None \\
\hline & & $\begin{array}{l}\text { Providing offices and workplaces that are well- } \\
\text { ventilated and with windows that allow natural } \\
\text { light to reduce electric consumption. }\end{array}$ & Management & $2020-2023$ & P 1 million \\
\hline & & $\begin{array}{l}\text { Replacing old electrical appliances with energy- } \\
\text { efficient models }\end{array}$ & Management & $2020-2022$ & $\mathrm{P} 500,000$ \\
\hline & & $\begin{array}{l}\text { Installing sensors that automatically switch on } \\
\text { lights only when there is a person in a room. }\end{array}$ & Management & $2020-2021$ & $\mathrm{P} 100,000$ \\
\hline & & $\begin{array}{l}\text { Unplugging machines and other electrical } \\
\text { appliances when not in use. }\end{array}$ & Department or Unit Heads & $2020-2021$ & None \\
\hline & & $\begin{array}{l}\text { Regular Inventory and maintenance of machines } \\
\text { and equipment. }\end{array}$ & $\begin{array}{l}\text { Department or Unit Heads } \\
\text { Repairs and Maintenance }\end{array}$ & $2020-2021$ & P50,000 \\
\hline \multirow[t]{4}{*}{2} & Water conservation & Using wastewater for non-potable purposes. & Repairs and Maintenance Unit & $2020-2021$ & None \\
\hline & & Using items for collecting rain like bins or drums & $\begin{array}{l}\text { Repairs and } \\
\text { Maintenance Unit }\end{array}$ & $2020-2021$ & None \\
\hline & & Using dual flush toilet converters. & Management & $2020-2022$ & P 100,000 \\
\hline & & $\begin{array}{l}\text { Installing automatic shut-off } \\
\text { or low-flow- nozzle faucets. }\end{array}$ & Management & $2020-2022$ & P50,000 \\
\hline \multirow[t]{4}{*}{3} & Proper waste management & Proper disposal of waste materials. & Repairs and Maintenance Unit & $2020-2021$ & None \\
\hline & & $\begin{array}{l}\text { Providing trash bins for proper segregation of } \\
\text { wastes. }\end{array}$ & Repairs and Maintenance Unit & $2020-2021$ & None \\
\hline & & Conversion of wastes into fuel & Management & $2020-2022$ & P100,000 \\
\hline & & $\begin{array}{l}\text { Conversion of wastes into other products or } \\
\text { upcycling }\end{array}$ & $\begin{array}{l}\text { Management } \\
\text { Production Department } \\
\text { Head }\end{array}$ & $2020-2022$ & $\mathrm{P} 100,000$ \\
\hline \multirow[t]{3}{*}{4} & Use of renewable energy & Investing in some form of renewable energy. & Management & $2020-2023$ & P1 million \\
\hline & & $\begin{array}{l}\text { Investing on solar panels and other equipment to } \\
\text { generate energy. }\end{array}$ & Management & $2020-2023$ & P1 million \\
\hline & & $\begin{array}{l}\text { Optimal utilization of natural lighting and natural } \\
\text { ventilation. }\end{array}$ & $\begin{array}{l}\text { Management } \\
\text { Repairs and Maintenance }\end{array}$ & $2020-2023$ & P300,000 \\
\hline 5 & eco-friendly packaging & $\begin{array}{l}\text { Redesigning packaging without compromising the } \\
\text { quality of the product. }\end{array}$ & $\begin{array}{l}\text { Production } \\
\text { Department Head } \\
\text { Management }\end{array}$ & $2020-2022$ & $\mathrm{P} 200,000$ \\
\hline \multirow[t]{2}{*}{6} & Reduce pollution & $\begin{array}{l}\text { Purchasing equipment and devices that are used } \\
\text { to prevent pollution. }\end{array}$ & $\begin{array}{l}\text { Production Department Head } \\
\text { Management }\end{array}$ & $2020-2023$ & P500,000 \\
\hline & & $\begin{array}{l}\text { Regular monitoring and maintenance of } \\
\text { machinery to reduce the emission of harmful } \\
\text { smoke and other gases. }\end{array}$ & $\begin{array}{l}\text { Repairs and Maintenance Unit, } \\
\text { Production Depart- ment Head } \\
\text { Management }\end{array}$ & $2020-2023$ & $\mathrm{P} 100,000$ \\
\hline \multirow[t]{3}{*}{7} & $\begin{array}{l}\text { Reduce Supplies } \\
\text { Consumption }\end{array}$ & $\begin{array}{l}\text { Recycling paper(using the back part of used } \\
\text { paper) }\end{array}$ & Department or Unit Heads & $2020-2023$ & None \\
\hline & & $\begin{array}{l}\text { Recycling or reusing bottles, jars, fabric } \\
\text { packaging materials, } \\
\text { and other reusable containers. }\end{array}$ & Production Department Head & $2020-2023$ & None \\
\hline & & $\begin{array}{l}\text { Using hand dryers in the toilets and wash area } \\
\text { instead of using tissue or hand towels. }\end{array}$ & Management & $2020-2023$ & P50,000 \\
\hline
\end{tabular}

The Green Economic Development Plan or G.E.D. Plan is a detailed proposal to perform business activities geared towards environmental protection while earning more profit due to reduced total costs and expenses. Handling the environmental tasks is part of the overall effort towards lean and clean energy systems in the 
manufacturing industry (Bellgran \& Bruch, 2015). The successful implementation of the strategies set in this plan will be a concerted effort of the management and the whole workforce of a business organization. The underpinning presumption is that financial success can be made consistent with ethical, environmental, and societal compliance (Dobers \& Wolff, 2000; Mohanty \& Deshmukh, 1998; and Stead \& Stead, 2000). The three-year plan would be useful for business enterprises to monitor green initiatives and foster a commitment to continue greening all processes, products, and services.

\section{Conclusions}

Based on the above findings, it was found out that sustainable development can be achieved by environmentally and socially responsible business enterprises that operate using eco-friendly processes to earn profits without compromising the environment. All small and medium enterprises had been in operation for less than half a decade and managed by the same person. All were manufacturing enterprises producing goods for consumption. Most of them are corporations. The small and medium manufacturing enterprises are all compliant with the requirements for the registration and operation of their business. The majority of the respondents have policies geared towards the protection of the environment. Some respondents had plans in implementing green initiatives, but those were not properly documented. The green initiatives implemented by the small and medium manufacturing enterprises resulted in reduced electricity, water consumption, usage of supplies and materials, and total repairs and maintenance expenses. The majority of the respondents reported higher net income because of the reduction in total expenses resulting from green initiatives that were implemented. The majority of the results from respondents did not have barriers to implementing green initiatives. Other organizations which were not established solely for profit may also pattern their business activities on the G.E.D. plan. This is to ensure that their resources were effectively and efficiently utilized.

\section{Conflicting Interests Declaration}

This research article's authors declared no potential conflicts of interest in line with the research, authorship, and publication.

\section{Funding Statement}

The authors received no financial support for the research and authorship of this research article.

\section{References}

Baines, T., Brown, S., Benedettini, O., \& Ball, P. (2012). Examining Green production and its role within the competitive strategy of manufacturers. Journal of Industrial Engineering and Manage- ment, 5(1), 53-87. doi:h ttp://dx.doi.org/10.3926/jiem.405

Ballada, W., and Ballada, S. (2018). Basic Accounting: Made Easy $21^{\text {st }}$ Edition. DomDane Publishers and Made Easy Books, Manila, Philippines.

Bellgran, M. and Bruch, J. (2015). Environmental Management in Manufacturing Industries. In Handbook of Clean Energy Systems, J. Yan (Ed.). DOI:1 0.1002/9781118991978.hces092

Beredugo, S. B. (2014). Environmental Accounting and Social Responsibility Disclosure on the Earning Capacity of Nigeria Manufacturing Firms. Journal of Economics and Sustainable Development, 5(14).w ww.iiste.org. 
Cassells, S. and Lewis, K. (2011), S.M.E.s and environmental responsibility: do actions reflect attitudes?.

Corp. Soc. Responsib. Environ. Mgmt, 18: 186-199. DOI:1 0.1002/csr.269

Dal Pont, J.-P., Azzaro-Pantel, C., Dal Pont, J.-P. and Azzaro-Pantel, C. (2014). Excellence in Manufacturing and Operations Control. In New Approaches to the Process Industries. DOI:10.1002/9781118984536.ch5

Dobers, P., \& Wolff, R. (2000). Competing with "soft" issues - from managing the environment to sustainable business strategies. Business Strategy and the Environment, 9(3), 143-150. http://dx.doi.org/10.1002/(SICI)1099- 0836(200005/06)9:33.0. C.O.;2-C

Eguia, I., Lozano, S., Racero, J., \& Guerrero, F. (2011). A methodological approach for designing and sequencing product families in Reconfigurable Disassembly Systems. Journal of Industrial Engineering and Management, 4(3), 418-435. doi:h ttp://dx.doi.org/10.3926/jiem..v4n3.p418-435

Field, B.C. and Field, M.K. (2009). Environmental Economics: An Introduction.5th ed. McGraw-Hill International Edition. Singapore, 286.

Jabbour de Sousa, A. B., Ndubisi, N.O., Roman Pais Seles, B.M. (2019). Sustainable Development in Asian Manufacturing SMEs: Progress and Directions Elsevier International Journal Production Economics. https://doi.org/10.1016/j.ijpe.2019.107567.

Marcus, P.A. and Willig, J.T. (1997) Moving Ahead with ISO 14000. New York: Wiley.

Mohanty, R. P., \& Deshmukh, S. G. (1998). Managing green productivity: Some strategic directions. Production Planning \& Control, 9(7), 624-633. $\underline{\mathrm{h}}$ ttp://dx.doi.org/10.1080/095372898233614.

Nassani, A. A., Aldakhil, A. M., Abro, M. M. Q., Zaman, K., \& Kabbani, A. (2019). Resource management for green growth: Ensure environment sustainability agenda for mutual exclusive global gain. Environmen- tal Progress \& Sustainable Energy, 38 (4), 13132.

Nguyen, HM, Onofrei, G, Truong, D, Lockrey, S. (2020) Customer green orientation, and process innovation alignment: A configuration approach in the global manufacturing industry. Bus Strat

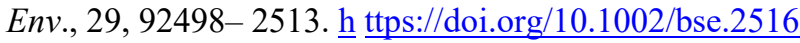

Ogega, O. M. (2017). Globalization and Global Warming: A Case of Laikipia County, Kenya. Journal of Energy and Natural Resource Management.

Peris, S. F., Kamisah Supian, M. Waliul, H., \& Md. Naim Hossain. (2020). A Mediating Effect of Green Market Orientation on the Environmental Performance: From a Literature Review to a ConceptualFramework. Journal ofManagement Info, $7(2), \quad 92-118$. https://doi.org/10.31580/jmi.v7i2.1421

Promotion of Green Economic Development(ProGED)-Philippines.

http://www.greengrowthknowledge.org/project/promotion-green-economic-developmentproged-Philippines.

Rowlands, C. (2019). The Increasing Demand for Eco-Friendly Products and Packaging. $\underline{\mathrm{h}}$ https://www.packageintegrity.com/single-post/2019/02/27/The-Increasing-Demand-for-EcoFriendly- products-and-Packaging

Stead, J. G., \& Stead, E. (2000). Eco-enterprise strategy: Standing for sustainability. Journal of Business Ethics, 24(4), 313-329. $\underline{\mathrm{h}}$ ttp://dx.doi.org/10.1023/A:1006188725928

Shoeb, A. (2015). Green Human Resource Management: Policies and practices, Cogent Business \& Management, 2:1, DOI: 1 0.1080/23311975.2015.1030817

Skrabania, L.(2018). Interview: RePack's Circular Packaging Solution for Online Retailers and Their Customers.November 19,2018.h ttps://en.reset.org/b log/interview-repacks-circular-packagingsolution-online-retailers-and-their-customers-11192018 (ac- cessed:November 22,2018).

Tu, J. \& Huang, H. (2015). Analysis on the Relationship between Green Accounting and Green Design for Enterprises. Sustainability 2015,7,6264-6277. DOI:10.3390/su7056264. 
Impact of Green Initiatives on the Financial Performance of Small and Medium Enterprises Ma. T. B. Alfaro, R. A. Diaz

Vachon S., Klassen R. (2008). Environmental Management and Manufacturing Performance: The Role of Collaboration in the Supply. Chain. International of Production Economics, 11 (2), 299-315

Waheed, A., Zhang, Q., Rashid, Y., Tahir, M.S., Zafar, M.W (2020). Impact of green manufacturing on consumer ecological behavior: Stakeholder engagement through green production and innovation. Sustainable Development, 28: 1395-1403. ․ㅡ ttps://doi.org/10.1002/sd.2093 